\title{
The Philosophy of Man
}

\section{in M. Gorky's Play "The Lower Depths"}

\author{
Olga V. Bogdanova* \\ St.-Petersburg State University \\ 11 Universitetskaya nab., St.-Petersburg, 199134, Russia
}

Received 13.03.2016, received in revised form 20.03.2016, accepted 24.04.2016

\begin{abstract}
A new approach to understanding ideological and philosophical structure of M. Gorky's play "The Lower Depths» (1902) is offered in the article. According to the analysis, it is not a dualistic opposition of the concepts of "verity" or "compassion", "truth" or "lie" that lies at the heart of the play, but progressive synthesis of the philosophical ideas, formed by the progression from the lowest to the highest. In contrast to the customary dualism, traditional for Russian Gorky's work studies, the triad of Gorky's philosophical ideas "paganism - Christianity - a new philosophy" that is consistently mediated by the ideas of Platonism, the doctrine of Leo Tolstoy and nietzscheanism is studied in the article. The article studies how the system of characters in Gorky's play has disintegrates into three conventional groups, through which the gradual evolution of formation of Gorky's image of Man is traced. The analysis shows how from the "wild" human-animals (according to Plato), through religious acceptance of one God (Christ), the characters of the play come to the highest step of the evolutionary ladder - to the Proud Man (following Nietzsche). Each of the Gorky's drama characters embodies a certain stage of ascension: Kvashnya, Nastya and the Baron are "wild" Plato's humananimals, the Actor and Luka are the representatives of the humanistic ideas of Christianity, mediated by the doctrine of L. Tolstoy, Satine is a premonition of the future ideal Proud Man praised by Gorky. In the course of the play analysis an assumption about who was a real killer of the shelter's owner Kostyloff is made and the interpretation of "ambiguous" final words of the play is offered.
\end{abstract}

Keywords: history of Russian literature of the 20th century, plays, M. Gorky, play "The Lower Depths", philosophical structure, the system of images.

DOI: 10.17516/1997-1370-2016-9-5-1089-1100.

Research area: philology.

Introduction. The play by Maxim Gorky “The Lower Depths" was written in 1902, it was staged in the same year and in 1903 it was first published. For more than a century of researchers studying the text of the play, an enormous amount of bibliographic sources has been accumulated, the play the analysis has been the subject of numerous monographs, anthologies, multi-authored books, etc., and the institutes for the study of the Soviet classic heritage were established. However, until today the play "The Lower Depths" is full of the neglected research puzzles, even now the text creates possibilities for new interpretations, related to the release of

(C) Siberian Federal University. All rights reserved

* Corresponding author E-mail address: olgabogdanova03@mail.ru 
scientific consciousness from the framework of the ideology of "socialist realism".

Statement of the problem. It is customary to think that paradiastole, proposed by Gorky: which is better, the truth or compassion, is fundamental in the interpretation of the play "The Lower Depths". However, modern analysis of the text reveals that the view, proposed by writer, has been interpreted narrowly and that the simplified scheme-opposition, represented by the playwright in a newspaper interview can be represented differently. This article is devoted to an attempt to identify different philosophical disposition of the play, to move away from the usual ideological antithesis "truth - lie" ("verity - compassion"), to discover other theoretical and philosophical foundations of the text.

Methods. Synthesis of the basic methods and principles of scientific research, among which, primarily, contextual (the techniques of historical, contrastive-comparative and intertextual analysis), phenomenological (including biographical) and formal and structural (typological and poetological) in their interrelation and complementarity form the basis of analysis.

Problem and analytical part. According to the traditional and established vector of Gorky's works study, fundamentally significant for the writer philosopheme of Man that organizes his ideological system, is central for the play "The Lower Depths". Accordingly, the alternative dilemma True / False that determines the basic paradigmatics of Gorky's theory, acts as a tool that reveals the ideological nature of the approved philosophy, its conclusiveness and validity.

However, even before the dramatic action, Gorky, at the level of introductory remark introduces a signal word that symbolically highlights another prospect of philosophical debates of drama-discussion. Already the first phrase - "Cellar that looks like a cave" (Gorky,
1986, 890) - detects the connection of Gorky's key ideologemes with Plato's eidos and uncovers mythopoetic allusions ${ }^{1}$. Plato's myth of the cave becomes an explicated "cipher" to perceive the semantic significance of the Gorky's play, the condition of overcoming specifics and a way to the scope of comprehension of human existence. With the help of hidden citations of the myth about the cave Gorky specifies the coordinates of the ideological dispute and sets boundaries of philosophical dispute about the man. Without bringing ancient Greek philosopher Diogenes on stage, the playwright reincarnated him out of stage through his unspoken, but audible in the subtext invectives: "I am Looking for Man!”.

Plato's implication in the text by Gorky is not limited by the metaphor of the world-cave. Already the next image-detail the keys that appear in the text of the opening remarks, actualizes Plato's understanding of truth as a transition from nonexistence to existence, overcoming the boundaries of enlightenment/unenlightenment. At the forefront of the stage space the playwright displays the image of Kleeshtsh-Charon, who was sitting, "trying the keys to the old locks", and "there were two large bundles of different keys, put on rings of wire at his feet" (Gorky, 1986, $890)^{2}$. Keys, as a capacious complex of meanings, symbolize the path of wisdom perception and hidden knowledge, a possibility of choice that a person gives to him/herself. The use of the archaism "arches" in the shelter description (Gorky, 1986, 890) gives the image of an invisible mystical arched door, the keys of which belong to the characters.

The image-motif of the dirt that creates the background atmosphere of the initial picture (a dispute about who will sweep the floor of the shelter lasts almost the entire first scene) is conceptually significant. The motif shows a genetic link with the theories of Plato, with his 
concept of the nasty nature of man, subjected to transformation and beautification.

Even to the greater extent the philosophical layer of the Platonic intertext is actualized in the scenographic composition of the play, in focusing activities around the motif of Plato's feast - a necessary condition for wise men-philosophers to enter into a polylogue, to agree with an opponent or challenge someone else's opinion, anyway to come closer to the understand the true nature of things. One of the most significant Plato's dialogues "The Feast" was made in that way, giving the opportunity to implement the main method of cognition for the philosopher dialectics, the art of sprouting the truth in disputediscussion. Gorky organizes metatextual space in the similar manner, revealing dialogical intentions of the characters by unusual for classical drama practice of Mise-en-scène. The use of "Plato's" intention is specifically represented in the final scene of the last act of the play by Gorky: the final monologues of Satin become the apotheosis of Gorky's eristic in the format of "The Feast" by Plato.

The essence of the component - inspiring and fertilizing Gorky's Thought largely derives from the ideological and metaphorical Plato's imagery. Thus, in the dialogue "Phaedrus", Plato reasons about the soul, which he represents in the form of a winged chariot drawn by two horses. The mind in Plato's chariot acts as a charioteer. In Gorky's work a "free friend of Man” Thought looks at everything and everywhere with a "vigilant and quick eye" to "trample everything old, everything tight and dirty $<\ldots>$ and create new on the forged by Thought, unshakable principles of freedom, beauty and respect for people" (Gorky, 1997, 44) (a poem "Man"). It is this idea (in very similar terms) that is expressed in the last "table-talk" of "The Lower Depths" by the most ideologically significant character of Gorky.
Emotional intentions of Gorky's characters, inner impulses of their actions, the etiology of behavioral manners and even love moderations of the characters are largely mediated by the Platonic pretext. In line with Plato implicits, images of the direct inhabitants of the cellarcave are presented in the drama-discussion. According to Plato, the unenlightened (or uninitiated) people, like cattle, comprise the lowest stage of the human hierarchy; their downto-earth animal nature dominates, revealing their zoomorphic features. In accordance with Plato, it is the embodiment of perverse souls, uncleared of dirt. It is in this way Gorky represents "cave dwellers" of the shelter - they either have "insect surname" (like Kleeshtsh) or make sounds like a beast growling (like Satine - "lying on the bunk and growls"), or get alias and abusive nicknames (Kvashnya "an old dog", Kleeshtsh - "a red goat", etc.). Establishing connection with Plato's dialogues on the basis of zoomorphic method appeared through and permeates the entire play (The Platonic Tradition, 2014).

All the characters of the cave express understanding the "unworthy" truths gradually, but consistently, in their own way exposing and illustrating a certain amount of truth by their own destinies. Appearing at the stage almost simultaneously, the characters gain "the right to express their opinion" sequentially, and in this sense it is important that dwellers of the shelter, who live in the kitchen (Kvashnya, the dumplings seller, the Baron and Nastya) start the dispute about the man and the truth. For Gorky (in the spirit of Plato) proximity to the kitchen becomes a sign and a reproach to the mankind in sinister and animal nature of their interests, aspiration to fill up their stomach. It is not by chance invectives of the final "feast" monologue of Satine are turned against satiety: "I have always despised people who are too concerned about being well-fed ... 
$<\ldots>$ The man is higher than satiety!..” (Gorky, 1986, 945).

Along with the motif of satiety there is the motif of the animal creatureliness and sinister love nourished by physiological impulses. Couples of the characters Kvashnya and Abramka, the Baron and Nastya, Pepel and Vassilisa illustrate PlatoGorky's idea of love at the targeted exposure sinister - level. The book "Fatal Love" ${ }^{3}$ in this context becomes a catalyst for a new type of the concept of life - truth-fiction, truth-illusion and truth-deception. The naive character prostitute Nastya who dreams of true love, transfers literary images into reality, substituting real life with them. Plato's myth of the cave shadows and reflections that "naive person" mistakenly takes as gospel, in Gorky's work finds exposition in Nastyonka's dreams.

In the context of the philosophical ideas of the play the concept-motif of work (action) takes on a function of kind of Platonic pretext developer. Plato's idea of work, clearly structured by ancient Greek society and distributed among socially useful citizens, is manifested in Gorky's play at the level of the original and primitive action - work, which is aimed at providing the consumer (and again "sinister") needs of the "wild" man. That is why the "former master" Baron accompanies Kvashnya to the market, Nastya sells herself and Kleeshtsh "creaks with the file". At the same time work for the sake of purity, beauty and light is not accepted by the shelter dwellers: after long dispute about sweeping the floor, i.e. getting rid of the dirt, none of the shelter inhabitants took a broom: up to a certain time the floor stays unswept. Satine's aphoristic maxim "When work is obligation, life is slavery!" becomes an indirect characteristic of the lower depth inhabitants, who are not free and are not able to find a way to cleanliness out the dirt independently.

Defocused in its plot and composition, the Gorky's play allows introducing the characters that were not previously involved in the dialoguesdisputes. In this sense, stand-alone, with a separate entrance-door small room that is located (according to the author's remark) on the opposite side of the kitchen, expositionally allows co-opting a new - alternative - character-type, familiar from the early prose by Gorky. Vaska Pepel is similar to Chelkash - "an inveterate drunkard and a clever, daring thief" who, "despite looking as a swindler", enjoys "notoriety and confidence" ("Chelkash"). However, individualistic traits that make up Chelkash's character are tempered in the image of Pepel. If Chelkash is about forty, he is "an old hunted wolf" with still black, but "pepper-and-salt" hair, than Pepel is young, he is twenty-eight, he is youthfully in love - and he prefers not fatal passion for beauty Vassilisa, but gentle care for soft and pure Natasha.

A dream of the protagonist of "The Lower Depths" becomes a signal to converging the images of Pepel and Chelkash, “... As if I am catching a fish, and I caught a huge bream! <..> And I prepared the net ... and I am thinking, now ..." (Gorky, 1986, 899). Note that Chelkash described peculiarity of the future work to his accomplice Gavrila as fishing, "We will go fishing. You will row..." It is known that since the ancient times fish was associated with the image of the Master, the Savior of the world, the forefather-sage. Fishermen were the first Disciples of Christ, assuring him that they will be "fishers of men". In this mythopoetic context Pepel's dream acquires the scope of ideologemesymbol of the forthcoming "fishing", the fishing of man's souls.

Meanwhile, Gorky takes the philosophical meaning of dream to subtext, bringing its interpretation by the unenlightened "savages" shelter's inhabitants as Pepel's winning his lover's heart ("It was not a bream, it was Vasilisa ...") to the forefront. The implication of the parable is obscured, love motif reduces the symbolic 
potential of Pepel's image, but enhances its realistic interpretation.

The name of the character supports the idea of the "frustrated" Chelkash in Pepel. Nickname Pepel can mean incineration of "the former man" in him, but, perhaps, still has unextinguished sparkles of humanity in him. In the context of Plato's philosophical ideas remnants, fumes and ashes of the past may be symbolized in Pepel's name - as "the ashes of the old truths" sound in the poem "Man". In any case, the image of Pepel is relegated by Gorky from the dominant position of royalty (Vasily, from the Greek Bazileus, "the king, the king's"), or romanticized image of Chelkash to illustrate procedurality of incarnation step by step. The statics of leitmotif is overcome in the play by its valence, different variants of life situations and the characters' judgments.

Plato's idealistic theory gave Gorky's play formal and compositional harmony and gave possibility to model the foundation of the global system. However, along with archaic ideas and symbols in the depths of Gorky's Platonism, the motifs of Christian imagery start moderately appear in the first act of the play. Plato's cave in some perspectives acquires the characteristics of hell (perhaps purgatory), the images of the shelter inhabitants are the examples of "evil spirit", and the characters actions are projectively associated with the Church (the aforementioned dream about fishing). In this context, the code of key is interpreted as the keys to the house of the Lord, from the (unattainable for the shelter inhabitants) Paradise. The bunch of keys is a signal to the variety of doors-ways that a person can choose for him/herself.

The Actor makes the most tragic, but also the most consistent choice in "The Lower Depths". The word "actor" ("artist") in the metaconcsiousness of the beginning of the $20^{\text {th }}$ century was accompanied by a symbolic meaning, and its motivic complex strived to build the model of the world with the maker-creator Man-Actor in the center (for example, in A. Blok's work). Unlike "simple" Anna or Kleeshtsh, naive Nastya, down-to earth Kvashnya - and the Actors is involved in knowledge and education. It is directly connected with the central dualistic pair Satine - Luka.

Already in the introductory remark Satine and the Actor are introduced by the playwright in not individualized, like the other characters manner, but "in pair", in a single line: "Satine and the Actor are about of the same age; about 40" (Gorky, 1986, 890). When the Actor appears on the stage, his first remark is addressed to Satine (Gorky, 1986, 893). However, the pairing of the characters is not a sign of similarity, but the explication of not severe confronting of the characters that has not reached its peak yet in the pre-positioning of the pair Satine - Luka.

Proximity of the Actor to Satine in the play is disavowed by the addiction of the both characters to the word. Just as Satin plays with unintelligible "inhuman" words, thus gaining respect in the eyes of the shelter's inhabitants (and within the dramatic action pushing the way to the future final monologue), and the "invisible" (in the introductory remark) Actor finds his visible essence to a great extent by the word. "The Actor (loudly, as if suddenly waking up). Yesterday, in the hospital, the doctor told me: your body, he said, is completely intoxicated by alcohol ..." (Gorky, 1986, 894). Against the background of the other characters the Actor as if is drawn in by being called the body - not (yet) a person, but a body, as if beginning its evolutionary development, that in the process of scientific Darwinism aspiring to be the Man. Through its (former) connection to the theater in the dispute about the Man the Actor opens the door of existential components of the "new time" and the renaissance (Shakespeare's) question "To be or not to be? ..." 
Meanwhile, the perception of the image of Hamlet changed for centuries, acquiring ambiguous and, in their own way, contradictory interpretations. Since the 1880 s, the period of the crisis of Populism, Hamletism was represented as a philosophy of pessimism, inactivity and phrase-mongering. That is why there is no desired (including by Satine) power in the "weak and feeble" Actor, deep understanding between Satine and the Actor does not happen - the motif of proximity/dissimilarity of the characters is given by Gorky gradually with the first phrases of the characters (Act 1) up to the last phrase of Satine in the final of the play (Act 4). In the scenic relations of Gorky's "Noah's Ark" with the "two of every kind", the Actor, to a greater extent, is a correlational pair to Luka than to the former telegraphist. According to the text, even before the appearance of Luka on the stage and after his disappearance, it is the Actor who becomes expression of a kind of counterpoint in relation to Satine, the personalized "deputy" of Luka. He notifies the appearance of the image of the wanderer-philosopher.

Sub-humans, half-beasts, "wild" people dramaturgically face the newly-found character Luka, on the one hand to explicate a new stage of the incarnation, and on the other to offer possible/impossible, permissible/ impermissible, according to Gorky, way of man's maturation. Previously dotted line of Christian imagery is personified in the character of Luka - it is not by chance the meaning of name Luka is "light" (lat.) (Tikhonov, 1995, 227). Conventionally, the darkness of "antiquity" is replaced by the light of "Christianity".

From his first phrases Luka earn the sympathy of the shelter dwellers and is perceived as a character with the vividly represented humanistic philosophy: "I don't care! <..> I think, no flea is bad: all of them are black, all jump ..." (Gorky, 1986, 900). An appeal to the oral folk art, to folk poetic maxima, and after a little while to the folk song that Luka sings: "In the middle of the night ... The path, the road we can not see ..." emphasizes the character among other characters, giving him a special place ${ }^{4}$. With Luka the action rises to a new level of the plot organization, a kind of compositional ladder. However, Plato, and after him Gorky did not consider sensible and spiritual knowledge about the world and about man elevated, or at least comparable with wise knowledge. In Plato's view, to know the truth means "to see $<i$ t $>$ with the mind". Rising distrust of the playwright to the philosophy of Christianity leads to the fact that Luka's appearance on the stage is immediately followed by the tonality of evaluation (or rather under-evaluation) of the character.

Meanwhile, a character that does not have another "small" voice, but discovers complete and capacious philosophy, that has ideological ideas of Christianity (already Tolstoyism) in its basis, appears on the stage. It is not by chance the very first phrases of Luka explicate the motifs of pity, sympathy and compassion. If at the beginning of the play Gorky-Plato showed the characters as a half-animals and half-beasts, with the appearance of Luka-Tolstoy the motifs-ideas that "all are equal ..." and "all are people" appeared in the text. From the first phrases Luka is involved in the dispute about the Man giving judgments about equality and brotherhood (Luka calls all the inhabitants of the shelter "brethren" or "brothers"), supports the "wild" and the "dark" fearful characters from the shelter.

The character-doer, but not an observer, Luka confesses folk wisdom "Water never flows <...> under settled stones ...” (Gorky, 1986, 931). It is significant that the action (to sweep the floor), which no one of the shelter dwellers did, was done by the person who was passing by (passing the road) - wanderer Luka. In the spirit of Plato, Luka equates the concepts of order and cleanliness, 
"there is no order in life ... and no purity..." (Gorky, 1986, 906), detecting the genetic link of the eidoses of disorder (chaos) - purity (space).

Categories of the semantic field of truth/ verity in Luka's presence are actualized persistently: whether it is Vassilisa's game with the meaning of words "bypasser" and "impostor" or railway trackman Medvedeff desire to find "order-law". In all the cases Gorky opposes "law" and "grace", mind and feeling, body and spirit, always identifying Luka with the latter. The philosophy of wanderer acquires the canon of the new "Gospel of Luka" (the version of Tolstoy's "Gospel of Leo"). Previously dotted Christian lines of hell or purgatory get categorical status, reaching the level of a religious philosophical system. Ancient Plato's philosophy enters into interactive relationships with Christianity, with the "figures of thought" of the modern times. Despite the fact that the name of Luka becomes the basis for an ironic and blunting pun Luka // deceitful ("What, Luka an old deceitful man ..." Pepel), nevertheless the character is the only one, whose speech influences the others. He not only philosophizes, he does work.

In the course of the play Luka addresses all the characters with the words of sympathy and consolation, however, Luka words affect the Actor more than the others. In the space of the pair Luka - the Actor "hidden" internal philosophicity of the Actor becomes more vivid. His words about the talent and "belief in yourself, in your strength ..." in comparison with Luka attitude allows to recognize the Actor's lack of active talent to life, his personal weakness. The former actor Sverchkov-Zavolzhsky (a pseudonym in the spirit of A.N. Ostrovsky) frankly admits to Luka, "And now ... it's over, brother! It's all over! ...<...> I, am dead, brother ..." (Gorky, 1986, 912). For a moment the Actor flashes ${ }^{5}$ next to Luka, recalls a forgotten poem about a madman, looking for (and quite successfully) earnings ${ }^{6}$, but is clearly aware of the fact that he has lost the main characteristic of man, "I have drunk my soul away, old man ...", and realizes the impossibility of conversion.

The favorite poem of the Actor about the "holy truth" and the "golden dream", the image of the madman-thinker who is able to illuminate the "whole world" remaining "without the sun", becomes a bright poetic dominant of the storyline of the Actor and a kind of apophatic - according to Gorky - glorification/precipitation of the image of the madman Luka. Death of the Actor, according to the playwright's intention, had to be a signal of Luka's consolations falsity and simultaneously the philosophical ideas of Christianity (and Tolstoyism). However, Gorky's character turns out to be a bipolar character, original synthesis of Platonism and Christianity is found in his life. On the one hand, according to Plato, poets and actors in their copying and reproduction of reality are doomed to the role of "false imitators", i.e. "weak", in their own way, people. But, within the framework of the Platonic system of values the choice of death was considered as an act of strong will. On the other hand, within the framework of orthodox views suicide is unacceptable and is condemned by the church. Meanwhile, Russian classical literature has created an elevated tragic sample of suicider Katerina ("Thunderstorm" by Ostrovsky), and within this paradigm the Actor's death is a strong and conscious choice, the reluctance to take life callously, without soul and faith. As well as for the Ostrovsky's character death was gaining freedom and getting rid of the tyranny of the "dark kingdom", and for the Actor, awakened by Luka's speeches, suicide has become a sign of revival the Man in him, able to understand and do not accept his own insignificance and smallness.

Other characters seem to be stronger than the Actor, for example Satine or the Baron, even realizing their position in the shelter, they accept their "empty", reflected (according to Plato), 
"invisible" sleepy life. Already in the first act Satine says thoughtful phrase about deadness of the lower depth, "... it is impossible to kill twice" (Gorky, 1986, 893). Nastya says about the Baron, "Just shut up... if God killed ..." (Gorky, 1986, 925). However, for both of them, these aphoristically accurate diagnoses remain phrases - "words, words!" While ideologically planned death of the Actors that had to signify the weakness of Luka' convictions, in fact, contrary to the author's intention, supported if not the philosophy of patience of Tolstoyan-wanderer, then definitely humanist tradition of classical Russian literature. In the final, killing himself "to death", the Actor disproves Satine's words that "it is impossible to kill twice", bringing his own understanding of the truth of life into dialogue-dispute. In the context of the Actor's death destinies of the shelter dwellers appear as Plato's "shadows", that are only reflections, imaginary silhouettes of the true existence on the blackened walls of the caveshelter.

As Gorky's text shows, there are no random episodes and depictions in the play, as the moments, accentuated by the playwright at the end of the third act, are represented as important, in anticipation and at the moment of the murder of the shelter owner Kostyloff.

At the end of the third act, more insistently than in the other scenes, the writer emphasizes the "invisible link" between Kostyloff and Luka. Their physical resemblance and internal antitheticity are deliberately marked at the level of their "mirror" reflected phrases, the characters first enter into dialogue with each other. At that Luka openly and suddenly, in a provoking manner, reveals his attitude to Kostyloff. In no other scenes of the play Gorky showed Luka being such bold and desperate.

Shortly before the murder of the shelter owner, Luka encourages Boobnoff to tell the story about the events that brought him to the lower depth of life - about Boobnoff's wife who "mixed up" with the dyer and decided to kill her husband, "... And I had decided to kill my wife $\ldots<\ldots>$ But I had realized before it was too late and I went away ..." (Gorky, 1986, 933). Satine, who soon afterwards appeared on the waste lot, tells a very similar situation about himself. Regardless of Boobnoff, unable to hear his story, Satine reveals how he "went crazy" - "killed the scoundrel in a fit of anger and irritation ..." (Gorky, 1986, 934). Just as two Luka's stories about Siberian exiles - about thieves in the country house and the "righteous land" - were linked by Gorky with signal-connector words, and in this case, two "family" stories are given in the text in "parallel" in deliberate proximity to the tragic events. Boobnoff and Satine's stories expositionally model the development of fight on the waste lot and projectively offer two of its variants. However, Gorky choses the third one.

It is customary to think that Pepel accidentally killed the shelter's owner. But with respect to Kostyloff's murder, the author's phrases keep some mysterious unrevealed details. Thus, during the fight, except Pepel and Kostyloff, Krivoi Zob and Satine beat as well. After Pepel's strong hit, the owner of the shelter falls. And Gorky comments, "Kostyloff falls in the way that only the upper half of his body can be seen around the corner" (Gorky, 1986, 937). The question arises: why should Kostyloff be almost invisible to the characters?

According to the stage arrangement of the characters, only Vassilisa, who, according to Luka, not only wanted, but was determined "to kill" her husband, stays next to fallen Kostyloff. At that, Vassilisa's cry for Kostyloff death "Murdered ..." - sounds after some time. Before it, a dialogue between Pepel who rushed to help Natasha and between Kvashnya and the Tartar, where each character has its own replica, is introduced to the text. Gorky as if "playing for 
time", at some point leaving Vassilisa alone, thereby creating a hypothetical possibility that "deviless" Vassilisa herself very "cleverly" dealt with her husband. But against the background of the previous daring and resolute Luka's behavior another assumption appears - an escaped exile (Siberia, absence of documents, "mysteriousness" of Luka were composition motif of the whole play) could kill Kostyloff. "The set of circumstances"declared departure, fallen old man Kostyloff unseen by anyone, a sense of impunity for the murder and "justice" - give reason to believe that even Luka might be the murderer. At that, Gorky deliberately keeps the secret of the old bloodsuckers' death, on the one hand by the plot, mysterious and tragic circumstances explaining the rapid disappearance of Luka who did not have passport, and on the other - transtextually, making "exculpatory" arguments in favor of Pepel's innocence and a reproach towards the rotten state system, which is unlikely to judge the character and his role in the tragic events fairly. Not accusing the character of the crime, Gorky, nevertheless, gives possibility for such an interpretation, creating a non-canonical parallel, in which the character-wanderer took the atoning sacrifice.

However, whoever was the true murderer, the sudden disappearance of Luka creates the most favorable conditions for the declaration and approval of the new - Gorky's own - philosophy of Man. As if outlining the evolution of the world philosophical ideas - from paganism (Plato) and Christianity (Tolstoy) - Gorky step by step rises up to the top step of the idea of the Good and the Man and goes to the presentation of his own version of a new world philosophy. It is not by chance at the beginning of the last act, the action of the play goes back to the original picture (paganism, Platonism), and Luka's ideas persistently sound at their background (Christianity, Tolstoyism), but the idea that "every time gives its own law ..." is represented as conceptually significant (Gorky, 1986, 939).

A solemn feast in the spirit of Plato in the final act (there was "a bottle of vodka, three bottles of beer and a big slab of rye bread" on the table) once again gives the characters a possibility to express their opinions and ideas. Gorky gives global scale to the coming philosophy - hence there is a poetic image-symbol of the wind in the author's remark.

Former telegrapher, a lover of words, sharpie Satine becomes Gorky's messenger of a new philosophy. The image of Constantine Satine is presented by strokes, without apparent physicality. The character enters a "wise conversation", he says catchy and aphoristic phrases, but does not take active part in the events of the shelter dwellers' life. Satine only "manifests" the characters, generating stereoscopy of vision with one or another "unknown" word at the level of subtext. By the word he "provokes" the characters to act (this especially regards the Actor), i.e. he takes over the function of Plato's dog ("growls") that manages the herd.

Among characters does and observers, Satine is an observer, a contemplator and that fact, according to Plato, makes him a philosopherthinker, "the lover of wisdom". However, Satine's mind is Gorky's and distinctive. He does not accept Luka's "pre-Christian” position. Tolstoy's forgiveness is unacceptable for him. But Satine can understand Luka's influence on the people of the lower depth, "Yes, this is him, old yeast $<\ldots>$ had an effect on me like an acid on an old and dirty coin ..." (Gorky, 1986, 941). The last getting rid of the rust, becomes, according to Gorky, the condition for awakening an advocate of the new philosophy in Satine.

In contrast to the later (self-) reflections of Gorky, where he argued that the "fundamental issue" of the play is the truth and compassion, the text evidences that in the process of its creation 
the playwright did not oppose Luka and Satine. According to the narrative idea of the play, Luka is not Satine's antagonist, but his forerunner. As a wanderer reasoned about the birth of the "better [man]" (Gorky, 1986, 941), and the writer in "The Lower Depths" develops the history of evolution of the ideas "for the best". At the turn of the centuries the idea of the Proud Man that was in the immediate vicinity to the theory of the superhuman by F. Nietzsche, became that "best" for Gorky. Following Nietzsche, Gorky wants to show mankind waking up to a new life by glorification of the absolute value of life, the superior Proud Man?

The ideal, according to Nietzsche-Gorky, may be implemented under condition of mankind coming back to the origins of history when life was ruled by the strongest - people who were not burdened by any domestic, social, or religious constraints, therefore they were absolutely free. According to the playwright's opinion, Christian religion denies freedom, humility deprives of independence and altruism restricts a person's choice. That is why it is important to revive the ideal of a strong and free personality - the ideal of antiquity - and give up the Christian cult of weakness and sacrifice. Although Gorky does not explain the essence of the proud man's truth, but his early romantic stories - "Makar Chudra", "Old Isergil", "Chelkash", etc. - leave no doubt what is the writer's ideal of Man. In this sense, Pepel, who has similar to the romantic tramp Chelkash attitudes towards life, "should" have become the character that could reasonably declare Gorky's idea in the last monologue of "The Lower Depths". But the circumstances of the plot and ideological plan (Vaska's arrest and a desire to keep the suspense with Kostyloff a secret) prevented the playwright to make Pepel the bringer of a new philosophical theory. However, Pepel's "not guilty" verdict (who probably was) innocent in Kostyloff death, gives possibility to talk about the "protective" tendencies in relation to the type of the character beloved by the writer.

Thus, to some extent coinciding with the actual Gorky's ideas about Man, Nietzsche's theory of the super human at this stage was the final step in the philosophical search for the young author, modelling the movement of the human species from the dirt and bestiality through faith and charity - to the Sun and a way out of the cave.

Resume. Based on the results of analysis of the play "The Lower Depths", we can confidently say that it was not the opposition, but the synthesis of the great theories of mankind that allowed, according to Gorky, to overcome the darkness of chaos and turn to the light and harmony of the cosmos. Philosophical triad "Paganism - Christianity - a new philosophy" became his one true model of the ideological structure that he fermented in the play "The Lower Depths". It was not a struggle between two ideologemes ("true - false" or "verity compassion") that was central for the play, but the idea of the harmonious progressive synthesis, leading humanity from the dirt and darkness to light, and the absolute and perfect Proud Man. Another thing is that the reality of life did not provide (did not create) the ground for the implementation of such utopian-romantic (youthful) representations of the writer.

\footnotetext{
In "The Myth of the Cave" Plato's Socrates offers his interlocutor to build a ghostly apparition, "You can liken our human nature in relation to enlightenment and unenlightenment to the following state ... look: in fact people are as if in the underground dwelling like a cave ..." According to Socrates, the cave represents a subjective society, the world of feelings and emotions, in which people reside. They can judge about the real - objective - world of ideas only by vague shadows on the cave walls. Only an enlightened person - a thinker - can get a real picture of the world of ideas, asking questions and seeking answers.

2 In ancient Greek mythology the image of Charon is accompanied by "a purse with a key (keys)".
} 
3 A novel by a modern German writer Ernst von Wildenbruch that translation into the Russian language appeared in the "New Journal of Foreign Literature" in 1901.

4 The time of the play creation and, as a consequence, frequent meetings with L.N. Tolstoy outstage explicate the implicit, but a deliberate reference to the personality and the nature of the humanist writer beliefs, emphasize the folk nature of Tolstoy's views and set ideological disposition (as a result - between Tolstoy's philosophy of inclusiveness and forgiveness and Gorky's effective humanism).

5 Satine calls the Actor "a stub". If we imagine that a candle stub is meant, the image turns out to be poetically capacious.

6 Let us note that similarity of the nature of Luka's work (swept the floor in the shelter) and the Actor is symptomatic.

7 In this context Satine's final phrase about the death of the ordinary man - the Actor, finds its ideological and narrative explanation.

\section{References}

Gorky, M. (1986). Na dne [The Lower Depths], In Gorky, M. Izbrannye sochineniya [Selected Writings]. Moscow, Khudozhestvennaya literatura, 890-951.

Gorky, M. (1997). Chelovek [The Man], In Maxim Gorky: pro et contra: anthology. St.-Petersburg, Izdatelstvo Rossiyskogo Hristianskogo Instituta, 43-48.

Tikhonov, A.N., Boyarinova, L.Z., Ryzkova, A.G. (1995). Slovar' russkikh lichnykh imen [Dictionary of Russian Personal Names]. Moscow, Shkola-press, 736 p.

Tradiciya platonizma [The Platonic Tradition] (2014), In Ancient Philosophy and the Classical Tradishion, 8 (1), 7-135. 


\title{
Философия Человека \\ в пьесе М. Горького «На дне»
}

\author{
О.В. Богданова \\ Санкт-Петербургский государственный университет \\ Россия, 199134, Санкт-Петербург, \\ Университетская набережная, 11
}

В статье предлагается новый взгляд на понимание идейной и философской структурьл пьесы М. Горького «На дне» (1902). Как показывает анализ, в основе пьесы лежит не дуалистическое противопоставление концептуальных понятий «истина» и «сострадание», «правда» и «ложь», но поступательный синтез философских идей, сформированных движением от низиего к высшему. В отличие от привычного дуализма, традиционного для отечественного горьковедения, в статье рассматривается триада горьковских философем «язычество - христианство - новая философия», последовательно опосредованньх идеями платонизма, толстовства и нициеанства. В статье рассматривается, как система персонажей пьесы Горького распадается на три условные группь, посредством которых прослеживается поэтапная эволюция формирования горьковского образа Человека. Анализ показывает, как от «диких» людей-зверей (по Платону) через религиозно уверовавших в единого Бога (Христа) герои Горького поднимаются на высшую ступень эволюичинной лестницы - к Гордому Человеку (вслед за Ницие). Каждый из героев драмы Горького воплощуает определенную степень восхождения: Квашня, Настя, Барон «дикие» платоновские люди-звери, Актер и Лука-представители гуманистических идей христианства, опосредованного толстовством, Сатин - предвестие идей будущего идеального Гордого Человека, воспеваемого Горьким. В ходе анализа пьесы высказывается предположение о том, кто в действительности убил хозяина ночлежки Костылева и предлагается интерпретация «двусмысленной» финальной фразы пьесы.

Ключевые слова: история русской литературы ХХ в., драматургия, М. Горький, пьеса «На дне», философская структура, система образов

Научная специальность: 10.00.00 - филологические науки. 